\title{
Missio hominum guided by an understanding of Ubuntu for missio Dei: Nico Smith's discovery
}

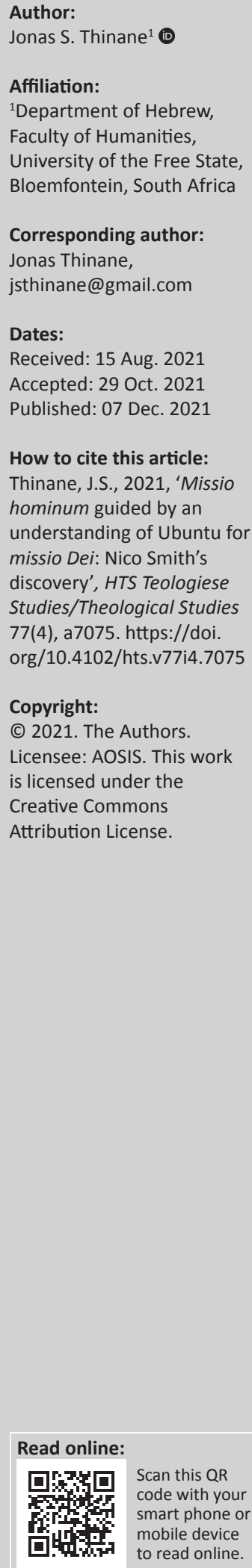

Missio hominum as a theological framework within the discipline of missiology in understanding missio Dei still lacks proper exploration. Few attempts have been made by theologians in the past but in different disciplines other than missiology. The exception is the previous studies by Nico Smith who investigated and conceptualised the subject at great length. This article builds on Smith's perspectives on missio hominum with the aim of providing an in-depth understanding of the subject in an African context. This shall be achieved by juxtaposing missio hominum with an African concept of Ubuntu through a literary analysis. Ubuntu is imperative in understanding the significance of human beings within the Christian mission in fulfilling the purpose of missio Dei.

Contribution: This article makes two important contributions in the field of missiology - first, by illustrating through missio hominum that human beings are God's partners in accomplishing his mission on earth, and second, by illustrating through Ubuntu that human beings should partner with one another for the same purpose.

Keywords: missio Dei; missio hominum; Jesus Christ; Nico Smith; ubuntu.

\section{Introduction}

All Christian missions such as missio Christos, missio Spiritus and missio ecclesiae play an important role in fulfilling the mandate of the missio Dei. Likewise, the role that people, especially Christians, play on their involvement in fulfilling the mandate of missio Dei over a period is at the focus of missiology. Scholars such as David Bosch, Nelus Niemandt, Timothy van Aarde, Johannes Kritzinger, Johannes Verkuyl, Willem Saayman and many others have put pens on paper to conceptualise human participation in the fulfilment of missio Dei's mandate. One such scholar, Nico Smith, wrote an article in 2002, 'From Missio Dei to Missio Hominum: En route in Christian mission and missiology,' in which he describes his personal path or commitment in Christian mission since the days of apartheid in South Africa, his encounter, described the concept of the missio Dei, his earlier understanding of Christian responsibility in fulfilling the missio Dei's mandate, and how he was faced with a series of questions that eventually led him to adopt a new much-needed paradigm for mission discover and introduce it as missio Hominum. This article believes that this necessary new paradigm is the missing link in the role that Christians should play with others in fulfilling the purpose of the missio Dei.

Scholars such as Musasiwa (2002), Knoetze (2017), Baron (2019) with the exception of Thinane (2021) tried to grapple with the concept of the missio hominum, but only stumbled upon its treatment of various scientific topics. This article goes much deeper into interpreting missio hominum from the perspective of Nico Smith, who uses the concept of Ubuntu to conceptualise what he meant by calling for mission hominum to be considered in the broader context of missio Dei.

This article will first introduce the concept of Ubuntu as it will be helpful in efforts to understand the missio hominum conclusions proposed by Nico Smith. Secondly, Smith's journey is briefly recited as he tried to relive his missionary course in which he discovered the need for missio hominum as the new paradigm aimed at outlining the role of humans in achieving the goals of missio Dei. Thirdly, it will go on to look at other angles of missio hominum, contextualising it within the broader mandate of missio Dei. Finally, it will juxtapose the unity of God the Father, the Son and the Holy Spirit on the way to fulfill the mission of missio Dei with the much needed unity of the people on their journey to participate in missio Dei through the paradigm of the missio hominum, influenced by the principles of Ubuntu. 


\section{Nico Smith and missio hominum}

In his excellent 2002 article, 'From Missio Dei to Missio Hominum: En route in Christian mission and missiology,' Nico Smith used various expressions to describe his previous perceptions of black people. These terms include, but are not limited to, first, black people as conversion objects. This is covered by Saayman (1991) when he noted that the entanglement of Christian mission and British colonialism remains alive in the minds of black mission objects (Saayman 1991:23). Secondly, he identified black people as infidels ready to be colonised (Smith 2002:4-6). Thirdly, as objects of colonisation and as pagans or uncivilised people. Saayman (2013) alluded to this fact by referring to the idea of white colonialists acting like wards of childish and uncivilised indigenous peoples of South Africa (Saayman 2013:137; Smith 2002:7).

These perceptions were coupled with his misunderstandings about what mission in general, and missio Dei in particular, is all about. Learning from the Dutch theologian Gisbertius Voetius, Smith believed that the mission was all about converting the nations, planting the church and glorifying divine grace and had sent him to convert the Venda people to Christianity because he truly believed that this would give honor and manifest the grace of God amongst the Venda people (Smith 2002:6). That is, although he worked with Venda people as subjects of his mission, his focus was not on them but more on God to impress him. He even goes so far as to say that during this mission he did not bother to accept or acknowledge the Venda as people who must be respected and recognised as such. But even after the concept of missio Dei was introduced from the perspective of the Willingen Conference of the International Mission Council in 1952, he still believed that it only meant that God was personally involved in the mission just to gather all people into the church, for he saw the church as the only channel through which God could reach the nations. He acknowledged that his new insight into missio Dei only meant that God was at the center in order to bring people further to the brink of mission (Smith 2002:10-11). For him, human participation in the missio Dei was important only as persons who had to be reconciled with God and not necessarily human-to-human reconciliation (Smith 2002:12).

\section{The notion of missio hominum}

First of all, it is important to define what missio hominum would represent in the broader context of other missions. Thinane (2021) mentioned that missio hominum consists of two Latin terms, namely missio and hominum, where the term missio is translated to the English term 'mission' and hominum is translated to 'humans', and both culminate in missio hominum, which translated means mission of humans. He further emphasises that missio Dei is about God's mission to reconcile people with Himself, while missio hominum is about reconciling people with people (Thinane 2021:3). While Bosch (2011) outlined that mission has several aspects, including peace, witness, justice, healing, fellowship, contextualisation, reconciliation and much more (Bosch 2011:512), missio hominum deals with total human reconciliation on earth to reflect the true image of God.

For Smith, missio hominum played an important role in eradicating and stamping out the legacy of apartheid, wherein people were alienated because of their race. For most South Africans, apartheid was a key idea of separation, as several guidelines were deliberately designed to separate or create perpetual divisions between people based on their skin colour. Smith realised that the apartheid policy was evil because it inherently denied the relational nature of the Triune God by separating people, which amounts to splitting the image of God (imago Dei), as all people are created in the image of God. Hence, his plea for consideration of the missio hominum was based on an understanding that adequate improvement in human relationships would in many ways conform to the eternal mandate of missio Dei. It is important for theological scholars, missiology experts and Christians, in general, to understand and be fully aware of the concept of missio Dei and its relation to other Christian missions. However, it is equally important to realise that human beings are not at all responsible or on the driver's seat of missio Dei, but instead God the Father, the Son and the Holy Spirit are the only designated drives of missio Dei project in its entirety. Human beings, on the other hand, participate in missio Dei on a partnership level by being active drivers of missio hominum as it influences human beings, in general, to be relational with each other just as the Holy Trinity is relational.

Nico Smith (2009) came across the concept of missio hominum when he realised that he could not serve or glorify God while neglecting relationships with other people, especially black people. For him, the incarnation of Jesus Christ in the perfect image of God should demonstrate the importance of human relationships. He excellently writes:

Gradually a new paradigm for mission developed in my mind by changing my understanding of mission as Missio Dei to Missio Hominum. If the incarnation of Jesus is to have real meaning. (p. 9)

It is through the scope of missio hominum that human beings will demonstrate the presence of God on earth, his concern and love for people. In this fashion, missio hominum become an agenda that God through the incarnation of Jesus Christ prescribed to all human beings (Smith 2002:18).

This article notes with overt concern that some scholars, such as Musasiwa (2002), have failed to fairly or adequately analyse Smith's introduction of the missio hominum in the context of other Christian missions. Musasiwa (2002:268) suggests that Smith suggested that missio hominum should replace missio Dei. In addition, he accused Smith of not being able to move from missio Dei platform to missio hominum, as he acknowledged that the missio hominum agenda was prescribed to the people by God himself through the Incarnation of Jesus of Nazareth. This claim in itself not only demonstrates the failure to properly understand Smith's 
work but also demonstrates the failure to understand the fundamentals of missio Dei as a fully God's mission, which merely directs the Church's participation in its course. As if this were not enough, incomprehension is further demonstrated by setting missio ecclesiae against missio hominum as if in a competition, suggesting that missio ecclesiae is more significant to missio Dei than missio hominum could ever be (Musasiwa 2002:269). Bosch (2011:28) initially dispelled such an attitude by pleading for an all-encompassing mission in which he tried to dissolve Christian tendencies towards alienation that think they are more important than all other people. Secondly, he dispelled them through the baptism and the transcending of barriers wherein he writes (Bosch 2011):

It is true of course, that the Pauline churches are intensely aware of what distinguishes them from those outside and that Paul also continuously reminds them of their uniqueness. At the same time, this awareness of being a distinctive group does not lead to any encystation, precisely their sense of uniqueness encourages them to share with others. (p. 28)

The fact that Christians are unique does not at all suggest that they are more significant than all other human beings as if Jesus himself did not teach his own followers to come second in the queue of importance amongst other human beings.

\section{God as one in missio Dei}

The idea of an inseparable and eternal God, who already in the Old Testament Genesis 1:26 and further through the Trinitarian formulas in Matthew 28:19, revealed himself ambiguously as the multifarious God, 1 Corinthians 12:4-5, 2 Corinthians 13:13, Ephesians 4:4-6, 1 Peter 1:2 and Revelation 1:4-5 are deeply entrenched and at the heart of the Christian belief system. In short, over the years of biblical interpretation, two views stood out: on the one hand, those who believed that God the Father, the Son and the Holy Spirit, although three are equal to one God; on the other hand, those who argued that Christ, though he is divine, can never be equated with God the Father. In the heat of these controversies, the Church had to appear in the form of the Council of Nicaea in 325 to clarify its position by defining the inseparable unity between God the Father and God the Son as it solemnly declared:

We believe in one God, the Father almighty, maker of heaven and earth, of all things visible and invisible. And in one Lord Jesus Christ, the only Son of God, begotten from the Father before all ages, God from God, Light from Light, true God from true God, begotten, not made; of the same essence as the Father.

While the Council of Nicaea had just declared the infallible union between the Father and the Son, the Council of Constantinople in 381 went further and included the Holy Spirit as a divinely equal member with the Father and the Son by declaring that the Holy Spirit is: 'the Lord and Giver of Life, who proceeds from the Father, who together with the Father and Son is adored and glorified'. These early Christian efforts in many ways formulated what is now known as the dogma of the Trinity. However, in the following centuries (5th century) up to modern days, this dogma was given more clarity in the work of St. Augustine, who summarised these discussions by using the Trinity as a starting point to define the inseparable relationship between God the Father, the Son and the Holy Spirit, rather than arguing about God the Father as the source of unity (Fortman 1999; Matthews 2002; Reimer 2019; Schaff 2016; Volf 1998).

Likewise, arguments or theories that contradicted the oneness of God and characterised the early history of Christianity broke out, leading to other views or movements such as Modalism, Sabellianism and Arianism being labelled heresies as they went against the Church's views on the Trinity. Firstly, according to modalist monarchianism, God the Father, the Son and the Holy Spirit are only used as instances or masks of an eternal God (Von Harnack 1961:166). One of the modalist proponents, a presbyter of the Church of Asia Minor around 230 AD, was God the Father who suffered (Marcovich 1986:403). This agrees with the view of Praxes of Smyrna, who viewed the Holy Trinity of God only as temporal modes comprising a divine substance (Durand 2007:39; Williams 2011:1539). This agrees with the view of Praxes of Smyrna who viewed Trinity or God's tri-unity as but a temporal mode comprising a divine substance (Durand 2007:39; Williams 2011:1539). Secondly, according to Sabellianism, attributed to its founder, Sabellius who was a priest and theologian during the third century denied a personal distinction of Trinity by arguing that the titles of the Father, the Son and the Holy Spirit are merely different aspects of one God. Sabellius further argued that God, without changing his own being, only manifested himself differently at different times for different purposes, that is, in creation as the Father, in the Incarnation as the Son and later as the Holy Spirit (Durand 2007:39; McGrath 2013:59; Williams 2011:1540). Thirdly, according to Arianism, borrowing from the views of its founder Arius, who strongly argued that Jesus Christ, although part of the Trinity, was merely an entity or creature through whom the only eternal God wanted to act with ultimate authority. Writing a letter to Bishop Alexander of Alexandria Arius outlined (Watts 2009):

We acknowledge one God, the only unbegotten, the only eternal, the only one without beginning, the one true, the only one who has immortality, the only wise, the only good, the only sovereign. (n.p.)

And that Jesus Christ as the begotten has a beginning, which essentially implied that there was a time in history when the Son did not exist (Allison 2012:20; Durand 2007:36-37; Oliver \& Oliver 2019:2-5). It is important to note, however, that while these theories attempted to challenge the divine abilities of Jesus and the Holy Spirit, they also recognised their significant and undeniable role in divine activities, including the missio Dei project.

Reimer (2019) pointed to scholars like Volf (1998) who did not state in so many words that mission, especially missio Dei, is actually the mission of the Trinity, suggesting that all three 
members of the Trinity are equally involved in misiso Dei. Pointing to what he calls 'Jesus' high-priestly prayer' as it appears in John 17:21, Volf (1998) suggested that this prayer presupposes the communion or eternal reunion that is required between the Triune God and His people, which essentially in many ways is the goal of missio Dei (Volf 1998:195). He then proceeded to write 'The mission of God in the world is a mission of triune God as Jesus in his great commission in Matthew 28:19-20 suggests' and further concluded that missio Dei is in actual fact missio trinitatis wherein the entire project of missio Dei follows the Trinitarian pattern (Reimer 2019:1). In fact, Arthur (2009) argues that the missionary has always been used to describe activities that involved the Holy Trinity in John 20:21 (Arthur 2009:1). This means that all three members of the Holy Trinity are equally responsible and committed as a committed community to achieve the goal of the missio Dei to reconcile the world with God or to restore a relationship with human beings as it was there from the original creation. Arthur (2009) also mentions that the Holy Trinity is the sole instigator of missio Dei and ultimately invites people to join in such a mission (Arthur 2009:3). While Kritzinger (2013:36) explicitly said about missio Dei: Mission is not an autonomous human action, but faithful participation in God's mission.

\section{The notion of Ubuntu}

The term 'Ubuntu' comes from the maxim of (isiZulu) Umuntu ngumuntu ngabantu, (isiXhosa) Umuntu ngumtu ngabantu, (Sotho and Tswana) Motho ke motho ka batho (FraserMoloketi 2009:243; Tutu 2004:25-26) (English probability) 'A person is a person because of others', the English version of this aphorism has no accuracy, as noted by Tutu (1999), simply translating it as my humanity is trapped, inseparable from what is yours (Tutu 1999:30). Mashau and Kgatle (2019) highlighted another indigenous Setswana saying that expresses the same idea - Kgosi ke kgosi ka batho meaning that kings can only rule through the support of their constituents. However, they did not just leave it there; instead they applied it within the church context saying Moruti ke Moruti Ka Phutego meaning a pastor is a pastor through the support of his or her congregants (Mashau \& Kgatle 2019:4).

Ubuntu simply means that the humanity of every person is embodied by other people. So no individual can claim to be human in the absence of other people, but individuals become human when they support and are supported by other people. Mashau and Kgatle (2019) sketch that through the bond of Ubuntu humans discover the true meaning and qualities of being human (Mashau \& Kgatle 2019:4).

Nolte and Downing (2019) found that while Ubuntu prides itself on being native to Africa and therefore compatible with most African cultures, most caring theories come from European and American theorists (Nolte \& Downing 2019:9). The term 'Ubuntu' can easily be understood as a reference to the essence or the art of being human and as an invitation to people to show humanity (Buqa 2015:4; Metz 2013:537).
To further clarify, Tutu (2004:31) says that it means: I am a person because I belong. It speaks of wholeness. It speaks of compassion. Shutte (2001) explains precisely that the concept of Ubuntu should be understood in terms of the human need to experience human fulfillment and growth only within the community or community of other people (Shutte 2001:2). As if ending the discussion about Ubuntu, Teffo (2002) suggested that Ubuntu is the human inner quality that makes those who use it more human (Teffo 2002:138). Koenane (2018) corroborated Teffos' view, referring to Mnyandu (1997), who excellently concluded that Ubuntu is not just about human qualities, but essentially about the one quality that enables people to be humanised to become true or whole human beings (Koenane 2018:7; Mnyandu 1997:81). Mbiti (1989) describing the relation of an individual with the community wrote:

Only in terms of other people does the individual become conscious of his own being, his own duties, his privileges and responsibilities towards himself and towards other people... Whatever happens to the individual happens to the whole group, and whatever happens to the whole group happens to the individual. The individual can only say: 'I am, because we are; and since we are, therefore I am'. This is a cardinal point in the understanding of the African view of human beings or humanity in its totality. (p. 106)

Ubuntu's existence is linked to the demonstration of human dignity, respect for one another, compassion and human concern for relationships. Elsewhere, Buqa (2015) pointed out that Tutu (2011) indicates that the concept of Ubuntu is centered on spiritual qualities such as hospitality, compassion, sharing, caring and generosity (Buqa 2015:4). This means that Ubuntu pursues values of humanity through compassion, sharing, caring, hospitality and generosity. Similarly, Nolte and Downing (2019) speak of the fundamental gesture of Ubuntu as a mutual act of deep human connection and solidarity (Nolte \& Downing 2019:9). These two elements (connectedness and solidarity) are principles on which African societies are built. In this article, the ideas of connectedness and solidarity refer to the level of social cohesion that is required in the broader context of the missio hominum to achieve the objective of the missio Dei.

\section{Human beings as one in missio hominum}

The earthly ministry of Christ in its entirety compels us to understand that his incarnation was intended to allow human beings to act as agents of the missio Dei in the world. Jesus Christ was fully aware that his earthly ministry could not be carried out without human accompaniment, so in the early days of his ministry he called the 12 and many others to be his companions on his journey, on which it was the mission of missio Dei is to be fulfilled. With regard to the call of the 12 to the discipleship, Bosch (2011), citing Pesch (1969), pointed out that this call was not made for its own sake, but through this call Jesus involved people in the service of God's sovereignty, and this was indicated by future involvement in the mission (Bosch 2011:39). Referring to Walter (1979), Bosch 
indicated that God himself asks for reconciliation with us, his enemies. This is how deeply God bows in partnership with people (Bosch 2011:141; Walter 1979:441). As if speaking on the absolute need for human beings to act as one towards the advancement of missio Dei, Bosch points to a call for a basic human reorientation wherein human beings become one and emphasise the spirit of togetherness than being apart or as opposed to a situation where human beings become wolf to one another (Bosch 2011:363, 408).

Aside from the calling of disciples, the New Testament is full of stories of how Jesus Christ, during his earthly ministry, brought people together to serve in missions. Expressing the will of the Father with whom Jesus Christ and the Holy Spirit are one, in Matthew 23 he says:

Jerusalem, Jerusalem, you who kill the prophets and stone those sent to you, how often I have longed to gather your children together, as a hen gathers her chicks under her wings, and you were not willing. (v. 37)

While in John 17 wherein Jesus Christ as one from whom the task of missio Dei springs prays for all his followers saying:

My prayer is not for them alone. I pray also for those who will believe in me through their message, that all of them may be one, Father, just as you are in me and I am in you. May they also be in us so that the world may believe that you have sent me. I have given them the glory that you gave me, that they may be one as we are one - I in them and you in me - so that they may be brought to complete unity. (vv. 20-23)

With regard to the ecumenical aspect of mission, Saayman (1991) argues that this type of unity is essential as it is based on or should reflect the unity of the three persons of the Holy Trinity (Saayman 1991:16). Similar to how Jesus Christ is completely divine in the presence of God the Father and God the Holy Spirit, the concept of missio hominum in the human context is solemnly based on the recognition that every person is completely human in the presence of other people. While missio Dei is more about God's overwhelming need to reunite with people, missio hominum is about God's overwhelming need for unity between people who will benefit missio Dei's mandate in the long run. This is recognised by Arthur (2009) as he argues that God desires that people live in absolute communion with one another; therefore the church is called to facilitate such communion (Arthur 2009:2-4).

In many cases, during his earthly ministry, Jesus Christ expressed his heartfelt desire to see unity amongst people. Precisely for this reason, Lohfink (2015:321) argues: 'Jesus came to unite God's people under God's rule, and he actually brought many people together in this new state'. Arthur (2009) speaks of a trinitarian relational theology in which people are expected to be relational and involved in the life of the other in order to achieve the closeness that is shown in the Holy Trinity. This means that mission hominum tries to connect people in such a way that their oneness relationship properly reflects the ever-prevailing relationship between God the
Father, God the Son and God the Holy Spirit. Speaking of non-negotiable mutual coordination of mission and unity, Bosch (2011) stresses that because the body of Christ is one, similarly God's people must be one (Bosch 2011:475). In fact, Bosch speaks of a triangular relationship that existed in which Paul is indebted to Christ, not just to Christ alone but also to Jews and Gentiles, and in return, Jews and Gentiles are not only committed to Christ but also to one another (Bosch 2011:171).

At this point, it is of the greatest importance to emphasise once again that missio Dei is more about God's work of redemption, which wants to reunite people with God, while missio hominum is about the process in which God has all human hearts ignited with the desire to be one with one another as God is one with himself (God the Father, God the Son and God the Holy Spirit). Missio hominum, as an aspect of missio Dei, tries more than anything to get people to find ways to relate to one another. It is through this aspect of the mission that God seeks to restore unity within human culture as explained in the creation account (Gen. 1:26) (Reimer \& Banda 2016:2).

\section{Missio hominum and Ubuntu for missio Dei}

Both missio hominum and Ubuntu are essentially about human coexistence and how such a union can or should contribute to achieving the goal of the missio Dei, according to which all reconciled people are to be reconciled to God. Bosch (2011) argues that Christians would jeopardise the mandate of the missio Dei if they choose to seek a relationship or reconciliation with God while neglecting reconciliation with other people (Bosch 2011:170). Both concepts equally recognise man's need to attain Holy Trinity unity, and both anticipate a society that demonstrates unity by living in harmony with one another. Through these concepts, human beings become whole or complete by first recognising the humanity of their fellow human beings.

Similar to Ubuntu, where people depend on each other's existence for their survival, the understanding of missio hominum suggests that people rely on a relationship they should have with one another so that firstly they reflect the image of God and second, to be able to fully participate in the eternal process of fulfilling the mandate of missio Dei. As with the understanding that the Holy Trinity is the foundation of missio Dei, the value of human relationships following the example of the Holy trinity is the foundation upon which the concept of mission hominum is built.

Knowing, understanding and interpreting the missio Dei are undoubtedly important for all people, especially for Christians. Christians, however, cannot pursue such knowledge and at the same time miss, or miss out on the task of building relationships with their fellow human beings, as the importance of such relationships for both mission hominum and Ubuntu is comprehensive and systematic in the 
fulfilment of the goals of the missio Dei. Bosch (2011) excellently contended that the church should be perceived as a community that is invested in creating new relationships not only with themselves but also with all members of the society; in doing this, he sustains that the church will be following the Lord of all human beings who is 'no private or individual Lord' (Bosch 2011:171). Similarly, Saayman (1991) agrees that the goal of the missio Dei can only be achieved through community and solidarity with other people (Saayman 1991:20). 'in Paul's understanding, mission is about saying to people from all backgrounds, welcome to the new community, in which all are members of one family and bound together by love' argued Bosch. He further underscored that for the Apostle Paul, each human being existed through a profound human solidarity and interdependence that prevails between the church and the world in its totality (Bosch 2011:170-171).

Missio hominum does not seek to steal the fame of the missio ecclesiae; it does not seek to steal the thunder from the uniqueness of the Christian community but rather tries to ensure that the Church is compatible with its call to bring peoples to Christ. In fact, according to Bosch (2011), there is a creative tension between exclusivity and solidarity with others. As part of missio hominum, Christians will build relationships with other people by demonstrating their unique lifestyle. It is precisely their feeling of uniqueness that encourages them to share with others, argued Bosch (2011:171). In addition to other Christian missions such as missio Christos, missio ecclesiae and missio Spiritus. The role of missio hominum paired with Ubuntu is to invite people into relationships who are to fulfil the goal of missio Dei. This is broadly in line with Thinane's (2021:4) argument that missio hominum includes or is about human demonstrations towards missio Dei's fulfilment.

The relationship between missio hominum and missio Dei is based entirely on the divine plan or God's eternal purposes for human salvation as anticipated by missio Dei. The principles of Ubuntu are demonstrated here by individuals only in so far as they seek to accomplish the eternal goal of missio Dei. Incidentally, missio hominum is inspired by the principles of Ubuntu and is thus guided by God's salvation master plan to achieve the goal of missio Dei (total human salvation). The principles of Ubuntu are inherently there to guide participants in God's mission to essential human values that include common human dignity, community, compassion, morality, solidarity, shared responsibility and humanity in order to ultimately achieve the goal of missio Dei. To sum it all up, missio hominum is all about Ubuntuinspired individuals or communities who are committed to achieving the goal of missio Dei.

\section{Conclusion}

Firstly, this article introduced the notion of Ubuntu to pave the way for understanding the implications of missio hominum as suggested by Professor Nico Smith. Secondly, it re-counted Nico Smith's journey from his missionary paths to the discovery of missio hominum as the new promising paradigm seeking to outline human participation in achieving the objective of missio Dei. Thirdly, it looked into other angles of missio hominum as it sought to place it within the broader order of missio Dei. Finally, it placed the mutual oneness of the Holy Trinity on the call of missio Dei alongside the oneness of human beings that is needed in their journey to participate and fulfil the call of missio Dei through the paradigm of missio hominum as guided by the underpinnings and foundations of Ubuntu.

\section{Acknowledgements Competing interests}

The author declares that he has no financial or personal relationships that may have inappropriately influenced him in writing this article.

\section{Author's contributions}

J.S.T. is the sole author of this research article.

\section{Ethical considerations}

This article followed all ethical standards for research without direct contact with human or animal subjects.

\section{Funding information}

This research received no specific grant from any funding agency in the public, commercial or not-for-profit sectors.

\section{Data availability}

Data sharing is not applicable to this research as no data were created or analysed in this article.

\section{Disclaimer}

The views and opinions expressed in this article are those of the author and do not necessarily reflect the official policy or position of any affiliated agency of the author.

\section{References}

Allison, G., 2012, Denials of orthodoxy: Heretical views of the doctrine of the Trinity, viewed 08 August 2021, from https://sbts-wordpress-uploads.s3.amazonaws. com/equip/uploads/2013/08/SBJT-V16-N1_Allison.pdf.

Arthur, E., 2009, Missio Dei: The mission of God, viewed 09 August 2021, from https:// www.kouya.net/upload/missionofgod.pdf.

Baron, E., 2019, 'The call for African Missional Consciousness through Renewed Mission Praxis in URCSA', Studia Historiae Ecclesiasticae 45(3), 19p. https://doi. org/10.25159/2412-4265/6184

Bosch, D.J., 2011, Transforming mission: Paradigm shifts in theology of mission, Orbis Books, Maryknoll, NY.

Buqa, W., 2015, 'Storying Ubuntu as a rainbow nation', Verbum et Ecclesia 36(2), a1434. https://doi.org/10.4102/ve.v36i2.1434

Durand, J.F.F., 2007, The many faces of God: Highways and byways on the route towards an orthodox image of God in the history of Christianity from the first to the seventeenth century, Sun Press, Cop., Stellenbosch.

Fortman, E.J., 1999, The Triune God: A historical study of the doctrine of the Trinity, Wipf \& Stock, Eugene, OR. 
Fraser-Moleketi, G., 2009, 'Towards a common understanding of corruption in Africa', Public Policy and Administration 24(3), 331-338. https://doi.org/10.1177/0952 076709103814

Knoetze, J.J., 2017, 'A long walk to obedience: Missiology and mission under scrutiny (1910-2010)', In die Skriflig / In Luce Verbi 51(2), a2192. https://doi.org/10.4102/ ids.v51i2.2192

Koenane, M.L.J., 2018, 'Ubuntu and philoxenia: Ubuntu and Christian worldviews as responses to xenophobia', HTS Teologiese Studies/Theological Studies 74(1), 4668. https://doi.org/10.4102/hts.v74i1.4668

Kritzinger, J.N.J. (Klippies), 2013, 'Mission in prophetic dialogue', Missiology: An International Review 41(1), 35-49. https://doi.org/10.1177/0091829612464746

Lohfink, G., 2015, Jesus of Nazareth: What He wanted, who He was, Liturgical Press, Collegeville, MN.

Marcovich, M., 1986, Hippolytus Refutatio Omnium Haeresium, Walter De Gruyter, Berlin.

Mashau, T.D \& Kgatle, M.S., 2019, 'Prosperity gospel and the culture of greed in postcolonial Africa: Constructing an alternative African Christian Theology of Ubuntu', Verbum et Ecclesia 40(1), a1901. https://doi.org/10.4102/ve.v40i1.1901

Matthews, G., 2002, Augustine: On the Trinity: Books 8-15, Cambridge University Press, Cambridge.

Mbiti, J., 1989, African religions and philosophy, 2nd edn., Heinemann Educational Publishers, Oxford

McGrath, A.E., 2013, Christian history: An introduction, Wiley-Blackwell, Chichester.

Metz, T., 2013, Ubuntu as a moral theory and human rights in South Africa, viewed 11 August 2021, from http://www.scielo.org.za/pdf/ahrlj/v11n2/11.pdf.

Mnyandu, M., 1997, 'Ubuntu as a basis for authentic humanity: An African perspective', Journal of Constructive Theology 3(1), 81.

Musasiwa, R., 2002, The quest for identity in African theology as a mission of empowerment, viewed 14 August 2021, from https://researchspace.ukzn.ac.za/ xmlui/handle/10413/3451.

Nolte, A. \& Downing, C., 2019, 'Ubuntu - The essence of caring and being', Holistic Nursing Practice 33(1), 9-16. https://doi.org/10.1097/HNP.0000000000000302

Oliver, W.H. \& Oliver, E., 2019, 'God as one', HTS Teologiese Studies/ Theological Studies 75(1), a4959. https://doi.org/10.4102/hts.v75i1.4959

Pesch, R., 1969, 'Berufung und sending, Nachfolge und Mission. Eine Studie zu MK. 1, 16-20', Zeitschrift fur katholische Theologie 91, 1-31.

Reimer, J., 2019, 'Trinitarian spirituality: Relational and missional', HTS Teologiese Studies / Theological Studies 75(1), a5348. https://doi.org/10.4102/hts.v75i1.5348
Reimer, J. \& Banda, Z., 2016, 'Doing mission inclusively', HTS Teologiese Studies/ Theological Studies 72(1), a3126. https://doi.org/10.4102/hts.v72i1.3126

Saayman, W., 2013, 'Mission as theological education: Is Christian mission history coming full circle?', Missionalia 41(2), 133-145. https://doi.org/10.7832/41-2-10

Saayman, W.A., 1991, Christian mission in South Africa: Political and ecumenical, University of South Africa, Pretoria.

Schaff, P., 2016, On the Holy Trinity. Doctrinal treatises. Moral treatises, Eerdmans, Grand Rapids, MI.

Shutte, A., 2001, Ubuntu an ethic for a new South Africa, Cluster Publications, Pietermaritzburg.

Smith, N., 2002, From missio dei to missio hominum - En route in Christian mission and missiology. undefined, viewed 12 October 2021, from https://www. semanticscholar.org/paper/From-missio-dei-to-missio-hominum-En-route-inand-Smith/a644474934ad1e3bf8602978d2427b86396c6624.

Teffo, L.J., 2002, 'Remaking Africa through a spiritual regeneration', in H.A.O. Mwakabana (ed.), Crises of life in African religion and Christianity, pp. 127-144, The Lutheran World Federation, Geneva.

Thinane, J.S., 2021, 'Missio hominum as the compassionate response to socioeconomic and vaccine challenges during COVID-19 in South Africa', HTS Teologiese Studies / Theological Studies 77(3), a6544. https://doi.org/10.4102/ hts.v77i3.6544

Tutu, D., 1999, No future without forgiveness, Rider, London.

Tutu, D.M., 2004, God has a dream: A vision of hope for our time, Random House, London.

Tutu, D.M., 2011, God is not a Christian: Speaking truth in times of crisis, Rider Books, London.

Volf, M., 1998, After our likeness. The church in the image of the Trinity, Eerdmans, Grand Rapids, Ml.

Von Harnack, A., 1961, History of Dogma, vol. 1, transl. N. Buchanan, Christia Classiscs Ethereal Library, Grand Rapids, MI.

Walter, N., 1979, 'Christusglube and heidnische Religiositat in paulinischen Gemeinden', New Testament Studies 25(4), 422-442. https://doi.org/10.1017/ S0028688500005166

Watts, J., 2009, 'Letter of Arius and his followers to Alexander', Unsettled Christianity, viewed n.d, from https://unsettledchristianity.com/letter-of-arius-and-his-followersto-alexander/.

Williams, D.H., 2011, Modalism. The encyclopeadia of Christian civilization, 1539-540, Blackwell Publishing Ltd, Oxford. 